\title{
Navigating the Lead Laws/Rules/Standards for Renovation and Repair Activities: A Guide for Contractors and Laborers
}

\author{
Alesia Ferguson*, Thomas Rimmer \\ Department of Environmental and Occupational Health, Fay Boozman College of Public Health, University of Arkansas for Medical \\ Sciences, Little Rock, USA. \\ Email: *aferguson@uams.edu, RimmerThomasW@uams.edu
}

Received July $16^{\text {th }}$, 2012; revised August $17^{\text {th }}$, 2012; accepted September $19^{\text {th }}, 2012$

\begin{abstract}
Children and adults are often exposed to lead in homes as a result of deteriorating lead-based paint surfaces and any disturbance to those surfaces. There are a number of laws, regulations, standards and guidance documents in place aimed at minimization of lead dust contamination following renovation and repair activities. These laws and regulations are oftentimes confusing and conflicting for the maintenance contractor who has limited time and resources for researching the right and appropriate course of action. This paper provides a comprehensive review and discussion of the lead laws, regulations, standards and guidelines for contractors.
\end{abstract}

Keywords: Lead-Safe Work Practices; Renovation Work; Lead Exposure; Construction Standards; EPA Renovation; Repair and Painting Rule; Weatherization

\section{Introduction and Background}

Lead is seen as one of the most harmful environmental toxicants for young children, with the predominant source being deteriorated lead-based paint. Between 1991 and 1994, it was estimated that 890,000 children in the United States had elevated blood levels over $10 \mu \mathrm{g} / \mathrm{dL}$ [1]; more recent data from the Centers for Disease Control and Prevention (CDC) puts that estimate at 250,000 [2]. Children are exposed when they inhale or ingest dust containing lead from outdoor and indoor sources. Other sources of lead include, but are not limited to: drinking water (where lead-containing solder or lead pipes are present), parental hobbies and work (e.g., making stained-glass windows and batteries, construction and laborers), and cultural home health remedies (e.g., azarcon used for upset stomachs) $[3,4]$. The goal of the CDC Healthy People 2020 initiative is to further reduce the average blood lead level for children from the mean value of $1.5 \mu \mathrm{g} / \mathrm{dL}$, as seen in the 2005-2008 National Health and Nutrition Examination Survey (NHANES), to $1.4 \mu \mathrm{g} / \mathrm{dL}$ [5]. It is estimated that 900,000 US workers engaged in construction are also at risk for lead exposure affecting their own health and that of their families due to take-home exposures [6].

For children, in particular, the absorption of lead can

\footnotetext{
*Corresponding author.
}

lead to irreversible neurological changes that exhibit themselves over time in loss of intelligence (lowered IQ) and problems with hearing, balance and memory. It can also lead to blood, central nervous and reproductive system damage [7-9]. Researchers suspect that there is no threshold of exposure to lead for many of these adverse outcomes, especially as a neuro-toxicant, placing far more children in the risk category for potential lead poisoning $[7,8,10]$. The problem of lead exposure is made worse by poor housing quality, poverty, and low parental education. Specifically, children of low socio-economic status have reduced access to proper diet, healthcare and educated parental guidance, factors that can mitigate exposure and absorption [9,11,12].

\subsection{History on General Laws and Standards for Lead}

Lead has long been used in consumer and building products offering an advantage as an inexpensive, hard, yet malleable material resistant to deterioration [13,14]. Driven by concerns over the safety of lead usage in the environment and the mounting evidence of lead as a neuro-toxicant, the United States has enacted a series of laws and regulations through the years to protect human and environmental health from various sources of lead exposure. The laws and regulations presented in the first 
part of this background section do not specifically affect renovation activity requirements, but illustrate a comprehensive approach to reducing environmental lead concentrations.

The Lead-Based Paint Poisoning Prevention Act of 1971 called on the Secretary of Housing and Urban Development to ban lead-based paint for residential use in homes receiving federal assistance and insurance, the Secretary of Health and Human Services to prohibit the use of lead in cooking, drinking or eating utensils, and the Consumer Product Safety Commission (CPSC) to prohibit the use of lead in toys and furniture [15]. In 1978, the CPSC effectively banned lead-based paint from all residential usage (including child-care facilities), lowering the limit of lead in paint used in these environments to a maximum of $0.06 \%$ [16]. More recently, based on the Consumer Product Safety Improvement Act of 2008 (Public Law 110-314), the CPSC established further protection for children's products with a stringent limit of no more than $100 \mathrm{ppm}$ of lead by August 14, 2011 [17].

The Residential Lead-Based Paint Hazard Reduction Act of 1992 (42 U.S.C., amended in 2005), and otherwise known as Title $\mathrm{X}$, further drew attention to the residential lead poisoning hazards for children and called for a national strategy to eliminate those hazards [18]. Based on this Act, the US Environmental Protection Agency (EPA) established certification and training programs for abatement workers, inspectors, supervisors, risk assessors and training providers, a grant program for lead hazard reduction, programs for the evaluation and elimination of lead hazards in homes receiving federal assistance, disclosure rules for the sale of property built before 1979, other considerations pertaining to financing, research, establishment of guidelines, and even recommendations for certification of those engaged in renovation activities. EPA and the US Department of Housing and Urban Development (HUD) first established acceptable levels of lead in dust or soil and around the home in 2001 based on a Final Rule entitled "Lead; Identification of Dangerous Levels of Lead" (40 CFR 745) promulgated under Title X [19]. Currently levels of lead not to be exceeded in floor dust, window sill dust, window well dust, bare soil in play area and yard soil are $40 \mu \mathrm{g} / \mathrm{ft}^{2}$ (444 $\left.\mu \mathrm{g} / \mathrm{m}^{2}\right), 250 \mu \mathrm{g} / \mathrm{ft}^{2}$ (2778 $\left.\mu \mathrm{g} / \mathrm{m}^{2}\right), 800 \mu \mathrm{g} / \mathrm{ft}^{2}$ (8889 $\left.\mu \mathrm{g} / \mathrm{m}^{2}\right), 400 \mathrm{ppm}$ and $1200 \mathrm{ppm}$, respectively.

Although EPA called for the gradual reduction of lead in gasoline as early as 1973, amendments to the Clean Air Act officially banned lead from gasoline used in most vehicles in 1996. Leaded gasoline is still allowed in the engines of off-road vehicles, aircraft, boats and farm equipment. Some new standards may be promulgated for leaded gasoline in piston engines that are thought to greatly contribute to ambient air lead levels. EPA is cur- rently installing monitoring stations at 15 airports throughout the country to better determine lead emissions from piston engine aircraft [20]. The air standard for lead under the National Ambient Air Quality Standards (NAAQS) was strengthened from $1.5 \mu \mathrm{g} / \mathrm{m}^{3}$ to $0.15 \mu \mathrm{g} / \mathrm{m}^{3}$ in 2008, with compliance required by 2017 [21]. Increasing stringency under the National Emission Standards for Hazardous Air Pollutants (NESHAP) has also being proposed by EPA as of April 2011 and specifically targets mercury and fine particulate release (which may therefore affect lead emissions) by establishing new maximum achievable control technology (MACT) standards for over 1350 coal and oil fired power plants [22]. Removal of lead from gasoline, and the other source reductions (e.g., targeting of power plants) should make the more stringent lead air quality requirement under NAAQS achievable.

Based on the 1974 Safe Drinking Water Act (amended 1986 and 1996), EPA has established standards for lead in water. A Lead and Copper Rule was also promulgated in 1991, with final revisions in 2007, which focused on monitoring drinking water at the tap with lead levels not to exceed $15 \mathrm{ppb}$ [23], replacing the early standard of 50 ppb at entry to the distribution system. The Lead and Copper Rule also requires suitable treatment techniques that reduce the corrosivity of water coming from the treatment plant. The Safe Drinking Water Act further limits the amount of lead that can be used in pipe and pipe fittings and fixtures to $0.2 \%$ lead for solder and not for than $8 \%$ by weight for pipes, pipe fittings, and well pumps [24]. This is an important fact for plumbers who also need to comply with renovations rules discussed later in this paper. The Lead Contamination Control Act of 1988 focuses on the school environment by recalling lead-lined water coolers in that setting [25].

The ultimate goal behind the series of laws and rules presented above is to reduce the level of lead poisoning for children and adults in the country. In 1991 the CDC lowered the acceptable blood lead level (BLL) or level of concern in children from $25 \mu \mathrm{d} / \mathrm{dL}$ to $10 \mu \mathrm{g} / \mathrm{dL}$, and most recently in 2012 to $5 \mu \mathrm{g} / \mathrm{dL}$ [26]. The US Occupational Safety and Health Administration (OSHA) through its General Industry Standards (29 CFR 1910.1025) and Construction Standards (29 CFR 1926.62) has established 40 $\mu \mathrm{g} / \mathrm{dL}$ as the maximum allowable BLL for workers in 1978 and 1993, respectively [27]. However, for adults without occupational exposure, an acceptable BLL is below $25 \mu \mathrm{g} / \mathrm{dL}[28,29]$.

\subsection{Specific Laws/Standard/Programs for Renovation Activities}

\subsubsection{Environmental Protection Agency (EPA)}

The residential lead concentration standards established by EPA can often be exceeded in homes containing 
lead-based paint during and following renovation, remodeling and painting activities. The disturbance and deterioration of lead based paint remain significant sources of exposure for young children and pregnant women today [30,31]. Consequently, on the $22^{\text {nd }}$ of April 2010 EPA implemented a new rule called Renovation, Repair and Painting Rule (RRP) issued under section 402(c)(3) of the Toxic Substances Control Act (TSCA). Under the rule, anyone compensated for renovation/repair work in homes or child-care facilities built prior to 1978 that disturbs 6 $\mathrm{ft}^{2}\left(0.56 \mathrm{~m}^{2}\right)$ or more of area on the interior or $20 \mathrm{ft}^{2}$ $\left(1.86 \mathrm{~m}^{2}\right)$ of area on the exterior will need to follow a series of mandates as described by the rule and attend an eight-hr training course to become a Certified Renovator [32]. Regardless of the amount of surface area, all window and demolition work is covered by the rule and lead-safe practices must be followed. The rule does not cover homeowners who make their own repairs on homes they live in, but does apply to landlords who renovate rental property themselves. The rule requires the use of EPA-approved lead test kits to confirm the absence of lead based paint, lead-safe work practices, visual inspection, a cleaning verification procedure, notifications to the public, record keeping, and certification of firm and individual renovators. The new RRP rule training and work requirements are based on earlier EPA/HUD training recommendations for lead-safe work practices which were derived from the 1992 Residential Lead-Based Paint Hazard Reduction Act. Initiation of the new RRP rule and upgrading of training materials seem to be the result of legal settlements with environmental and public health advocates [33], and is enforceable through fines and possible criminal court sanctions.

Currently, the states of Alabama, Iowa, Kansas, Massachusetts, Mississippi, North Carolina, Oregon, Rhode Island, Utah, Washington, and Wisconsin are authorized as EPA RRP State Programs. These programs may have more stringent implementation and enforcement for their programs than other states, so contractors are encouraged to visit and review these programs thoroughly, especially if wanting to conduct renovation activities in multiple states. Participants trained under any previous EPA/HUD lead-safe work practices courses need to take the EPA RRP four-hour refresher course to come into compliance with the new rule. There are opportunities through certified trainers for on-line training of the six-hour portion and separate in-class workshops for the two-hour handson portion [34].

Previously, in December 2008, EPA implemented a separate, but associated, rule (Pre-Renovation Education Rule, TSCA 406b) mandating that contractors (now called "renovation firms" under the EPA RRP rule) give out a new educational booklet called "Renovate Right", to tenants and owners prior to conducting any renovation activities in homes or child-occupied facilities built before 1978. The rule requires that a signature page from the "Renovate Right" booklet be signed by the recipients and kept with other RRP records for at least a period of 3 years by the renovation firm as evidence of receipt. Since 1996, based on the Toxics Substance and Control Act (TSCA 406a) the federal government has required that known lead-based paint presence and lead-based paint hazards be disclosed by sellers and by landlords by handing out the pamphlet "Protect Your Family from Lead in the Home" and any other relevant home assessments. All leases, rental agreements and real estate sales agreements must also contain wording to ensure that disclosure and notification actually takes place [35].

Contractors occasionally confuse the requirements for lead abatement with the requirements for lead renovations. The EPA RRP is meant to address renovation, repair and remodeling activities that disturb lead paint, but EPA's TSCA 402 Abatement Rule (40 CFR 745 subpart L), which has been in effect since 1996, covers inspecttion, risk assessment and abatement by firms and individuals, where abatement means the permanent and intentional removal of lead hazards. Abatement can include permanent enclosure or encapsulation, or complete removal of lead hazards in the residence $[19,36]$. The EPA abatement rule has already been widely adopted by 39 authorized states based on 40 CFR, Part 745, subpart E and Section 404 of the TSCA [37].

There has been some discussion of including comercial and public buildings in the new RRP rule [38]. If the RRP rule is extended to cover commercial and public buildings, the building date for applicability may be more recent than the 1978 limit for residences and child-care facilities. It should be stressed in RRP training classes that contractors will need to check the EPA RRP web site routinely for updates to stay in compliance.

\subsubsection{Department of Housing and Urban Development (HUD)}

HUD rules on lead-based paint address varying levels of activities in federally assisted or federally owned housing. Federal assistance programs can range from those under the Housing and Urban Development Act of 1965 to those under the United States Housing Act of 1937. Other federal agencies which may also fall under the HUD standards include the Farmers Home Administration, the Resolution Trust Corporation, the Federal Deposit Insurance Corporation, the General Services Administration, the Department of Defense, the Department of Veterans Affairs, the Department of the Interior, and the Department of Transportation [39].

HUD's Lead Safe Housing Rule, (24 CFR 35, subparts A through R), was promulgated to implement the LeadBased Paint Poisoning Prevention Act of 1971, and the 
Residential Lead-Based Paint Hazard Reduction Act of 1992. The rule applies to pre- 1978 homes when $2 \mathrm{ft}^{2}$ $\left(0.19 \mathrm{~m}^{2}\right)$ or more of interior area or $20 \mathrm{ft}^{2}\left(1.86 \mathrm{~m}^{2}\right)$ or more of area outside is being disturbed. Often forgotten is that the rule also applies if 10 percent of the total surface area of an interior or exterior type of component with a small surface area is also being disturbed (e.g., window sills, baseboards, and trim). Renovation and repair activities as defined by EPA RRP align with HUD's definition for rehabilitation in the Lead Safe Housing Rule and typically apply to homes receiving federal assistance under $\$ 5000$ for rehabilitation work [39]. The HUD Lead Safe Housing Rule is a lengthy regulation which contractors often find difficult to understand due to a range of different required activities dependent on the level of funding. Under HUD's Lead Safe Housing Rule, contractors are also referred back to EPA's rules for abatement activities and certification procedures which apply at higher levels of federal funding.

\subsubsection{Department of Energy (DOE)}

As established by 10 CFR, Part 440, weatherization assistance through the DOE is meant to target low-income families, and aims to reduce energy costs for the customers while ensuring a basic comfort level, especially for children and the elderly [40]. Service to low-income families often means working in older homes in poor repair, leading to possible disturbance of lead-based paint surfaces during weatherization related activities such as window replacement, blower door tests, and insulation of walls and attics. DOE established the need for lead-safe weatherization as outlined in their Weatherization Program Notice (WPN) 02-6, Weatherization Activities and Federal Lead Based Paint Regulations and later in WPN 08-6, Interim Lead-Safe Weatherization (LSW) Guidance, created in 2002 and 2008, respectively [41]. DOE has also established guidance for health and safety measures (most recently in the 2011 WPN 11-6), which now mentions the use of an EPA Certified Renovator and trained crews in lead-safe weatherization when working in pre1978 homes [42]. The Montana Weatherization Center has developed a lead-safe weatherization (LSW) curriculum approved by DOE that covers work practices tailored for weatherization activities as outlined in Table 1 [43]. A $\$ 5$ billion expansion of the Weatherization Assistance Program, part of the 2009 American Reinvestment and Recovery Act, highlighted the work protocols and requirements for safe and effective weatherization activities, including lead-safe weatherization [44].

\subsubsection{United States Department of Labor (DOL)}

The Occupational and Health Administration (OSHA) has had regulations for the protection of workers involved with lead since 1971. These rules began with a
Permissible Exposure Limit (PEL) of $200 \mu \mathrm{g} / \mathrm{m}^{3}$ as an 8-hour time-weighted average (TWA) airborne exposure maximum to be achieved by engineering and work practice controls. In 1978, with the promulgation of 29 CFR 1910.1025, OSHA lowered that PEL to $50 \mu \mathrm{g} / \mathrm{m}^{3}$ for workplaces other than construction and agriculture. Other parts of the regulation included provisions for medical surveillance, paid removal from exposure in the case of elevated blood lead levels, hygiene facilities, appropriate respirators, and exposure monitoring. Not until 1993, as a result of Title $\mathrm{X}$ and growing evidence of exposure in the construction sector, did OSHA promulgate its final Lead in Construction Standard (29 CFR 1926.62) that provided rules comparable to those for general industry, including a PEL of $50 \mu \mathrm{g} / \mathrm{m}^{3}$ and an Action Limit (AL) of $30 \mu \mathrm{g} / \mathrm{m}^{3}$ as an 8-hour TWA [45].

In the Construction Standard, the employer must implement mandatory employee protective measures prior to and during initial exposure assessment of certain tasks (e.g., manual dry scraping, manual demolition, and heat gun application on lead painted or coated surfaces) presumed to generate lead exposures greater than the PEL. Those mandatory employee protective measures amount to implementing a worker protection program and should at a minimum include: hazard determination (including exposure assessment through air monitoring), medical surveillance and provisions for medical removal, job-specific compliance programs, engineering and work practice controls, respiratory protection, protective clothing and equipment, housekeeping, hygiene facilities and practices, signs, employee information and training, and recordkeeping. For hazard determination objective or sufficient historical data (i.e., actual employee monitoring data obtained within the last 12 months) can be used to satisfy the requirement for an initial exposure determination, except for those tasks covered by 1926.62(d)(2). The engineering and work practice controls can be seen as equivalent to the lead-safe work practices covered under HUD and EPA. Employers are encouraged to read the Lead in Construction Standard for complete comprehension of OSHA requirements. Figure $\mathbf{1}$ is a categorical summary of the requirements of the OSHA Lead in Construction Standard.

As mentioned above, the standard includes a respiratory protection program and references the OSHA Respiratory Protection standard 29 CFR 1910.134 for proper respirator selection and program requirements. An acceptable respirator program must include the following: procedures for selecting respirators appropriate to the hazard, medical evaluation, fit testing procedures, procedures for proper use of respirators in routine and reasonably foreseeable emergency situations (including cartridge change schedules), procedures and schedules for cleaning, disinfecting, storing, inspecting, repairing, 
Table 1. A comparison of DOE, EPA and HUD rules for lead safe work practices.

\begin{tabular}{|c|c|c|c|}
\hline & DOE LSW & EPA RRP & HUDLSHR \\
\hline Application & Pre-1978 homes & $\begin{array}{l}\text { Pre-1978 homes and } \\
\text { child care facilities }\end{array}$ & $\begin{array}{l}\text { Pre-1978 homes and } \\
\text { child-care facilities }\end{array}$ \\
\hline Areas & $\begin{array}{l}\text { Level 2: }>6 \mathrm{ft}^{2} \text { interior or } \\
>20 \mathrm{ft}^{2} \text { exterior and all windows; } \\
\text { Level } 1 \text { otherwise }\end{array}$ & $\begin{array}{l}>6 \mathrm{ft}^{2} \text { interior or } \\
>20 \mathrm{ft}^{2} \text { exterior }\end{array}$ & $\begin{array}{l}>2 \mathrm{ft}^{2} \text { interior or } \\
>20 \mathrm{ft}^{2} \text { exterior }\end{array}$ \\
\hline $\begin{array}{l}\text { Assumption of } \\
\text { lead-based paint }\end{array}$ & $\begin{array}{l}\text { Yes, unless absence confirmed } \\
\text { by qualified individual }\end{array}$ & $\begin{array}{l}\text { Yes, unless EPA approved } \\
\text { test kits confirm absence }\end{array}$ & $\begin{array}{l}\text { Presence or absence must be confirmed } \\
\text { by lead inspector/risk assessor }\end{array}$ \\
\hline $\begin{array}{l}\text { Notification and posting } \\
\text { of warning signs }\end{array}$ & Required & Required & $\begin{array}{l}\text { Required, notification required } 15 \text { days } \\
\text { prior }\end{array}$ \\
\hline $\begin{array}{l}\text { Protective sheeting on } \\
\text { floor beneath job } \\
\text { ( } 6 \text { mil poly sheeting) }\end{array}$ & $\begin{array}{l}5 \mathrm{ft} \text { in all directions (interior) } \\
\text { and } 10 \mathrm{ft} \text { in all directions } \\
\text { (exterior): Levels } 1 \text { and } 2\end{array}$ & $\begin{array}{l}6 \mathrm{ft} \text { in all directions (interior) } \\
\text { and } 10 \mathrm{ft} \text { (exterior) }\end{array}$ & $\begin{array}{l}6 \mathrm{ft} \text { in all directions (interior) } \\
\text { and } 10 \mathrm{ft} \text { (exterior) }\end{array}$ \\
\hline \multicolumn{4}{|l|}{ A) Interior } \\
\hline Two-layer door flap & Required (level 2) & Required & Required \\
\hline Cover furniture & $\begin{array}{l}\text { Required (level 2) with } 2 \\
\text { or } 4 \text { mil poly sheeting }\end{array}$ & Required with 6 mil poly sheeting & Required with 6 mil poly sheeting \\
\hline $\begin{array}{l}\text { Close windows, cover vents, } \\
\text { Turn-off HVAC if feasible }\end{array}$ & Required (level 2) & Required & Required \\
\hline Zip walls (e.g., barrier walls) & Required (level 2) & Recommended for dusty jobs & Recommended for dusty jobs \\
\hline \multicolumn{4}{|l|}{ B) Exterior } \\
\hline Cover windows within 10 feet & Required (level 2) & Not required & Not required \\
\hline Close windows within 20 feet & Required (level 2) & Required & Required \\
\hline $\begin{array}{l}\text { Vertical containment } \\
\text { on windy days }\end{array}$ & Required (level 2) & $\begin{array}{l}\text { Required (also } 10 \mathrm{ft} \\
\text { adjacent property) }\end{array}$ & Required \\
\hline $\begin{array}{l}\text { Cover or remove } \\
\text { furniture on outside }\end{array}$ & Required (level 2) & Required & Required \\
\hline \multicolumn{4}{|l|}{ DURING the JOB } \\
\hline
\end{tabular}

Prohibited practices for paint removal (must always comply with these regardless of diminis level)

Examples for specific
job activities
Wet methods, clean routinely

END-OF-JOB

Use of HEPA vacuum and wet methods

Visual inspection

Cleaning verification (inside only)

Clearance testing

OSHA lead in

construction standard

Report to clients
Number of prohibited practices not clear, at least 4 alluded to. Weatherization crews are advised to follow the HUD 6 prohibited practices.

(3): No open flame burning or torching; no heat gun over $1100^{\circ}$ use of HEPA-attached, vacuum shrouded power tools

Given for weatherization activities

Required

Not given

Required

Required

Required by workers and certified renovator

Required using EPA verification cards

Not required

Not required

Detailed discussion

(insurance liability also mentioned)

Specific weatherization

forms through agencies

Mentioned briefly
(6): No open flame burning or torching; no heat gun over $1100^{\circ} \mathrm{F}$ or that chars paint; HEPA-local exhaust control for machine sanding or grinding, and for abrasive blasting or sandblasting, no dry sanding or scraping unless within 1 foot of electrical outlet, no chemical stripper in poorly ventilated space

Not given

Required

Required

Required by workers and supervisor

Not required

Required by lead inspector/risk assessor/dust sampling technician

Mentioned briefly

Test kit report within 30 days and

Post renovation form as soon as Specific HUD forms through agencies possible

The work practice standards are grouped to the left under SET-UP (interior versus exterior), DURING THE JOB and END OF JOB activities for the contractor to better understand some of the difference between agencies. In addition, contractors should be aware of difference in the requirements for a de-minimis level for which the standards apply, and also variations in who can test for the presence of lead-based paint. Some conversions for standards: $2 \mathrm{ft}^{2}\left(0.19 \mathrm{~m}^{2}\right), 6 \mathrm{ft}^{2}$ $\left(0.56 \mathrm{~m}^{2}\right), 10 \mathrm{ft}^{2}\left(0.93 \mathrm{~m}^{2}\right), 20 \mathrm{ft}^{2}\left(1.86 \mathrm{~m}^{2}\right)$. 


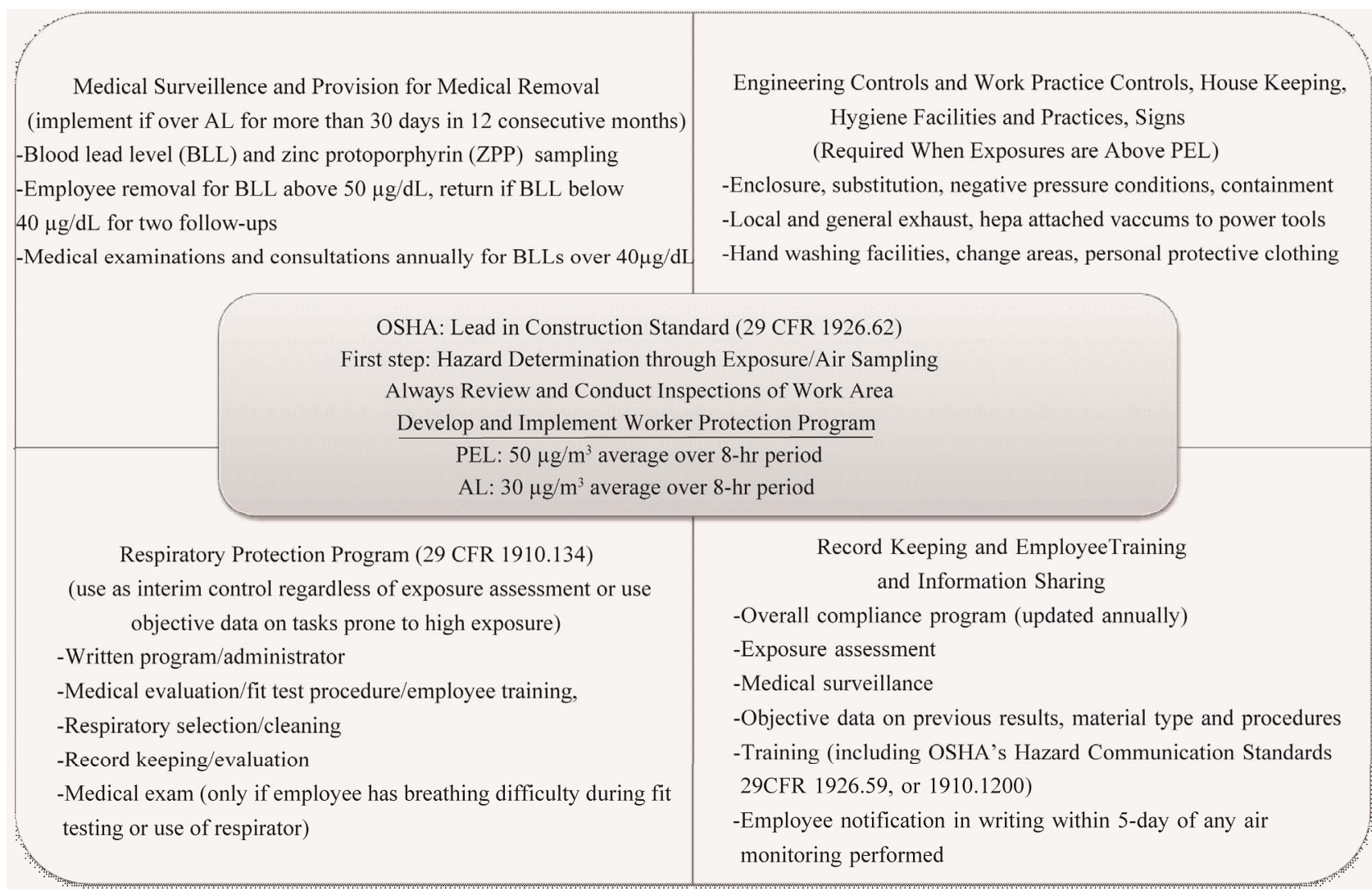

Most contractors (unless a sole proprietor) must also comply with the Lead in Construction Standards when working around lead-based paint. The Respiratory Protection (29 CFR 1910.134), and the Medical Surveillance and Provision for Medical Removal Programs are components of the OSHA standards and employers must reasonably comply. Some of the engineering and work practice control, along with hygiene practices and requirements for the posting of signs, are similar to those lead work practice requirement by EPA, HUD and DOE.

Figure 1. OSHA's Lead in Construction Standards summarized.

discarding, and otherwise maintaining respirators, training of employees in the respiratory hazard to which they are potentially exposed during routine and emergency situations, training of employees in the proper use of respirators, (including putting on and removing them, any limitations of their use, and their maintenance), medical examination if needed, procedures for regularly evaluating the effectiveness of the program, procedures to ensure air quality when supplied air is used, a written program and designation of a program administrator, and recordkeeping procedures.

The employer must select the appropriate respirator according to 29 CFR 1926.62(f)(3)(i). A respirator is required in the interim (prior to hazard determination), when the employee is exposed above the PEL, or at the employee's request. All respirators for lead protection must be HEPA-rated (100 designation as defined by NIOSH), and must be of the full face piece type if the lead air contaminant causes skin or eye irritation, or warranted due to higher levels of exposure. The employer must provide a powered air-purifying respirator when an employee chooses to use this respirator and it will provide the employee adequate protection. The level of respiratory protection can only be reduced when the employer demonstrates that the actual employee exposures are below the PEL.

There is a distinction between a medical evaluation and a medical exam. All employees who are required to wear respirators must be given a medical evaluation per CFR 1910.134. This is a questionnaire that is filled out by the employee and evaluated by a licensed health care professional, and is completed before fit testing. If the employee is given a clearance, based on this evaluation, and then has trouble wearing a respirator during the fit test, then medical examination must be provided. Contractors are advised to review the NIOSH technical report, "Preventing Lead Poisoning in Construction Workers" and "NIOSH's Pocket Guide to Chemical Hazards" on the appropriate use of respirators $[46,47]$.

\section{Discussion}

\subsection{Comparison of Work Practice Standards for EPA, HUD and DOE}

In an attempt to comply with the rules for renovation established by the various agencies, contractors often get 
confused when determining which requirement applies under various circumstances and when, and also in determining the best approach when a work practice conflict exist. Table 1 addresses the main work practices that apply to rehabilitation activities under the HUD Lead Safe Housing Rule, renovation and repair activities under the EPA Renovation, Repair and Painting Rule, and those lead-safe weatherization activities found in the curriculum designed for the DOE's Lead-Safe Weatherization Program. Once it is established that lead-paint is present and the de-minimis area of disturbance set by agency requirements is met or exceeded, the work practices standards can be divided into set-up, during the job and end of job requirement/activities.

For set-up, notification and posting of warning signs are required by all agencies, where HUD requires at least a 15-day notification to tenant/owner. EPA has special requirements for delivery of the "Renovate Right" booklet and acquirement of signature page based on renovation location (i.e., single family home, apartment building, or child-care facility) and availability of tenant/ owner or child-care director/owner. For interior containment, all of the agencies require poly-sheeting on the floor beneath and extending beyond the work area, door flaps, covering of furniture in the work area with polysheeting, and sealing/closing of all windows and doors (though the sheeting thickness and extent vary somewhat). DOE is the only agency that requires "zip walls" (floor-to-ceiling barriers for partial-room work) for all jobs over $6 \mathrm{ft}^{2}$ on the interior. For all agencies, Heating, Ventilation and Air Conditioning (HVAC) vents/systems should be sealed and shut-off if possible and discussed with client/tenant. Although not mentioned in agency curriculums, the HVAC return vent can be covered with a High-Efficiency Particulate Air (HEPA) filter in extreme weather conditions and where personal protective equipment (PPEs) make conditions uncomfortable or hazardous for HVAC unit to be turned off. For exterior work, all agencies require poly-sheeting on the ground, $10 \mathrm{ft}$ in all directions from the work area and the closing of windows within $20 \mathrm{ft}$. DOE also requires the covering of windows within $10 \mathrm{ft}$ of the job activity for exterior work. All agencies recommend vertical containment on windy days and the establishment of perimeter marking $20 \mathrm{ft}$ $\left(1.86 \mathrm{~m}^{2}\right)$ in all directions of the job on the exterior using barrier tape and warning signs. Vertical containment refers to barriers constructed to prevent the spread of lead dust to adjacent properties and may require the construction of scaffolding to keep the barriers in place. Recently, EPA has included a requirement for vertical containment within $10 \mathrm{ft}\left(0.93 \mathrm{~m}^{2}\right)$ of a adjustment property.

During the job, all agencies require the use of personal protective equipment (PPE) including at least coveralls, painter's hat, booties and a respirator. Optional PPE mentioned includes safety goggles and disposable gloves, with sealing of all openings of PPE with duct tape or painter's tape. In order to control the generation and spread of lead contamination, the agencies list a variety of prohibited practices for paint removal, including six specific actions for HUD and three for EPA (see Table 1). Within the DOE curriculum prohibited practices are not clear, but all of the HUD prohibited practices are alluded to as best practice. All recommend the use of wet-methods and routine cleaning during renovation jobs. All of the agencies warn of safety hazards falls on plastic sheeting; fire and shock hazards from improper use of power equipment and the use of wet-methods close to electrical outlets and the way to deal with waste-water containing lead. This water must be captured, filtered, and disposed of carefully down toilets only, with the filtered material going in approved trash bags with rest of the lead waste. Lead-contaminated water from powerwashing on the exterior, although seemingly difficult to collect, is still required to be disposed of in a similar fashion. Contractors should be sure to check with their local water treatment authority for further guidance for the handling and disposal of lead-contaminated wastewater.

At the end of the job the use of an approved HEPA vacuum and wet cleaning methods are mentioned by all agencies with warnings to the contractor to avoid takehome exposures via clothing, and tools. Renovators may see some variation in cleaning methods, and there are studies that recommend particular best practices $[48,49]$. Following cleaning and the proper disposal of all lead waste, all agencies require visual inspections by crew/ workers, followed by visual inspection by a supervisor (in the case of EPA a certified renovator must conduct the final and official visual inspection). For interior work only, EPA's visual inspection requirement is followed by cleaning verification which requires the contractor to take wipe samples of the work area and compare the color on the wipe cloths to verification cards provided to the contractor during training (really a dust comparison method). HUD's visual inspection is followed by a clearance testing by a lead risk assessor or inspector. Clearance testing requires laboratory quantification of lead levels on floor, window wells, window sills, and possibly outdoor bare soil in play area and yard soil to meet EPA established residential standards. Renovators are cautioned to perform additional cleaning to meet these standards under HUD, and clearance testing is always an option for EPA certified renovators or to appease tenants/owners who want clarification on removal of lead hazards. EPA allows renovation jobs to be supervised by the Certified Renovator where trained (but non certified) workers can be left on the job site once containment of the work area 
has been established. The Certified Renovator is allowed to field train his/her workers in eight different lead-safe work practices (e.g., laying plastic, making a door flap, proper clean-up activities). HUD states that all workers need to receive the full eight hour structured classroom training, preferably the new required EPA RRP eight-hr training to become Certified Renovators.

\subsection{What Rule Applies}

Anyone compensated for performing renovations and repair activities in a home built before 1978 must comply with the new EPA RRP regulation, and this includes work conducted under other federal agencies. EPA's RRP requires that all jobs be conducted by an EPA certified firm (even a federal agency or branch of a federal agency may be required to become a certified firm), using a Certified Renovator and if needed (non-certified) trained workers. With the new EPA RRP also comes the requirement for documentation and retention for at least three years of the following: Lead test results, notification of renovation work to be conducted (including signature page from Renovate Right Booklet), implementation of lead-safe work practices, and evidence of end of job cleaning verification. In addition, there is an established procedure for notification to EPA of trainings being conducted by certified trainers, and notifications of individuals who have received the 8-hour training to become a certified renovator (note that notification requires the collection of an individual's picture, address, passing exam grade, and birth date). The recordkeeping procedures for certified renovators could potentially provide a hindrance to employment of undocumented immigrant workers in the construction business. Finding sufficient certified trainers to conduct the trainings in Spanish could also provide a hindrance for Latino contractors and laborers. Some states currently have no certified trainers that can conduct the training in Spanish. Individuals can search the EPA website for available trainers (at http://cfpub.epa.gov/flpp/searchrrp_training.htm).

When work is conducted in a federally assisted or federally owned property, the additional and stricter rules of the HUD Lead Safe Housing Rule may also apply. Table 1 shows that these primarily refer to: 1) a smaller deminimis area on the interior for complying with the law and use of lead-safe work practices $\left(2 \mathrm{ft}^{2}\left(0.19 \mathrm{~m}^{2}\right)\right.$ instead of $\left.6 \mathrm{ft}^{2}\left(0.56 \mathrm{~m}^{2}\right)\right)$; 2) the involvement of a lead inspector/risk assessor to determine the presence and extent of lead hazards at the start of the job; 3) the requirement for a clearance test by a inspector/risk assessor at the end of the job; 4) the adherence to 6 prohibited practices instead of the 3 described in the EPA RRP rule; and, 5) classroom training for all workers. All other aspects of the EPA RRP still apply.

Weatherization crews performing weatherization for the Department of Energy must also comply with EPA RRP, and may also have to comply with HUD Lead Safe Housing Rule if worked is being conducted in a property receiving additional assistance through another federal agency listed by HUD's Lead Safe Housing Rule. There are some areas of the DOE weatherization curriculum that are in fact stricter, and more conservative than EPA RRP or the HUD Lead Safe Housing rule for renovation activities. As Table 1 indicates, there are 2 levels of requirements for weatherization jobs, where all weatherization jobs involve some measure of lead-safe practices. Less than $6 \mathrm{ft}^{2}\left(0.56 \mathrm{~m}^{2}\right)$ of area being disturbed on the interior and less than $20 \mathrm{ft}^{2}\left(1.86 \mathrm{~m}^{2}\right)$ on the exterior is described as Level 1, requiring at least protective plastic sheeting on the floor beneath the job activity. In addition, zip walls (i.e., barrier walls) are a must for Level 2 activities which are only mentioned for dusty jobs on the interior or windy day jobs on the exterior under HUD and EPA renovation rules (this is often described as vertical containment). When confusion arises, the contractor is advised to take the measure most protective of human health (theirs and those of the tenants), rather than the least expensive choice.

Other areas of the law can seem in conflict. For example, the EPA RRP advises contractors to follow the federal policy on disposal of lead waste, unless there is a stricter state of local policy stating otherwise. EPA's policy (EPA-HQ-RCRA-2001-0017) allows contractor-generated lead-based paint waste in residences (e.g., single family homes, military barracks, public housing) to be disposed of as regular household waste. The intent behind this policy is to lower renovation costs and encourage more removal of lead hazards from the home environment [50]. One could reason also that this prevents the accidental spread of lead waste if transported by contractor vehicles. DOE, for weatherization jobs, normally recommends that weatherization crews take generated waste back to agency offices for proper disposal. It is unclear whether the transport of lead waste requires a hazardous waste transport license, and whether it would be better for weatherization crews to leave lead waste behind for residential disposal, as allowed by law. In some rural areas, residents may not have routine pickup of garbage, but dispose of household waste through burning or dumping at unregulated sites. In these cases, weatherization crews should remove lead-waste for proper disposal. Regardless of the final means of disposal, any lead waste must be properly secured and gooseneck sealed in strong contractor trash bags (normally 3 mils in thickness for HUD and EPA, or 6 mils for DOE) and placed in covered containers outside until removed. Doubling of bags may be needed for sharp or heavy objects.

Contractors are reminded that if they work on a childcare facility located in a commercial building (such as an 
office space or factory) or a non-residential public building (such as a school, or hospital) building, the rules for the disposal of lead-waste change. In commercial and nonresidential public buildings, the waste should be subjected to a "hazardous waste determination" if over 220 lbs (100 kg) according to the Resource and Recovery Act of 1976 (RCRA) and the Hazardous and Solid Waste Amendments of 1984 (HSWA) [51,52]. This rule might apply to a residence converted to a child-care facility if it then becomes a public building. Again, contractors are advised to check with local or state regulations for further guidance.

\subsection{Applying OSHA Regulations to Renovation Work}

OSHA rules typically apply to all employers, with exceptions for public employers (those are covered under State Programs) and those that are self-employed. Even small firms conducting renovation activities fall under OSHA and the home environment becomes the workplace setting. In an analysis of 2003-2005 data from 30 states using the National Institute for Occupational Safety and Health (NIOSH)'s Adult Blood Lead and Surveillance (ABLES) program, about 533 adults of the 13,724 surveyed meet the OSHA criteria for medical removal from a workplace. Of these individuals, painting and wall covering contractors demonstrated the highest rate of removal at $29 \%$, followed by all other construction workers at $14 \%$, whereas battery manufacturing was only 3\%. This study and others that examine BLL for construction and repair workers continue to demonstrate the high exposures for the construction industry and the need for regulations on safe lead work practices [6,53,54], not just through HUD and EPA but the need for additional compliance with OSHA regulations.

There is some difficulty, especially for small companies, in following all aspects of the OHSA Lead in Construction Standards. Some elements of the regulations are often thought to be expensive, time-consuming or inconvenient. In a 2002 San Francisco study which included 32 small contractors and their employees, even after OSHA training of employer and employers, there was lack of full compliance. The more difficult objectives not met a year after training (although improvements were seen) included: use of HEPA exhaust sanders, wet methods for clean-up activities and surface preparation, blood lead testing and the prohibition of eating, drinking and smoking in the work area. Other problem areas identified by this study included hazardous waste disposal and liability insurance. Researchers did see a significant improvement in the usage of half mask respirators, identification of lead based paint with colorimetric testers and the use of protective covering on floors, for example [55]. Some of the objectives and problem areas listed above are not specifically required by the standard. The OSHA lead standard states that the PEL is to be achieved, to the extent feasible, by any engineering and work practice controls. Some work practices such as cleaning by dry sweeping or compressed air are specifically prohibited by the Standard, however.

The recent introduction of the new EPA RRP and its widespread application to small and large firms throughout the nation should mean more consistent use of leadsafe work practices, lower lead air concentrations in those environments, and lowering of blood lead levels for workers, especially if there is credible enforcement. If followed, the EPA RRP work-practices, including use of respirators and avoidance of the prohibited practices, may provide sufficient protection given the unlikelihood that most contractors will comply with all the OSHA requirements for air monitoring, medical surveillance, and a more detailed respiratory program. Self-employed contractors that do not fall under OSHA will greatly benefit from the EPA RRP, its lead-safe practice requirements and even recommendation for use of disposable N-100, R-100 or P-100 respirators.

Larger construction firms and weatherization agencies that have more resources could feasibly implement more components of the OSHA Lead in Construction Standards. The application of air monitoring to the renovation jobs that greatly vary in length and environment can prove difficult, but the respiratory protection program including fit-testing and training is more practical and feasible. Given that weatherization crews deal with additional hazards in homes such as asbestos and mold and often work in confined areas such as attics and crawl spaces, a respiratory protection program is highly recommended. Regarding air monitoring, DOE recommends that agencies perform sufficient air monitoring tests on specific weatherization activities to demonstrate that hazardous air concentrations for workers are not being exceeded. These tests are called negative initial determinations (NID), records of which are kept on the job site. There is some indication that DOE is collecting information from states and organizations and hopes to receive an exemption from air monitoring requirements under OSHA [56].

There is a wealth of studies providing information on specific renovation tasks that lead to high air and surface concentrations of lead [57-60]. These include, for example, interior scraping, exterior scraping, window renovation, uncontrolled power sanding and demolition activities. Factors affecting those concentrations include: The use of wet methods, ventilation, containment preparation, and proportion of paint removed, as well as the type of contractor (e.g., painting, environmental remediation contractor, general contractor). Studies like these influence the creation of the basic standards under the EPA RRP, 
in particular the prohibited practices, requirement for the level of respiratory protection, and for the required cleaning verification procedures. DOE will still need to establish the need for air-monitoring for specific weatherization tasks, such as performing blower door tests, installing windows and insulating attics.

\section{Conclusion}

It is important for the contractor/laborer to understand that there is research and science behind the making of these laws and regulations meant to protect everyone from the dangers of lead. Renovation activities have been shown to leave lead dust and debris behind in homes that then pose a hazard to children and pregnant women, in particular. During the renovation job and after, contractors can also be exposed to the hazards of lead based paint. With increased knowledge on the best work practices the contractor can reduce the hazard for all. The EPA RRP applies to every contractor/worker who works on pre-1978 homes and child-care facilities. Those working on federally assisted properties built before 1978 or for someone receiving federal assistance, where that property was built before 1978, must comply with the EPA RRP and the HUD Lead Safe Housing Rule. Those working with weatherization agencies under DOE must comply with DOE lead-safe weatherization, EPA RRP and sometimes also with the HUD Lead Safe Housing Rule. Finally, unless a contractor is a sole proprietor with no employees, they must also comply with OSHA Lead in Construction Standard. The contractor must determine which law and work practices apply and when in doubt, use the work practice that will leave the least amount of lead dust behind.

\section{REFERENCES}

[1] J. L. Pirkle, R. B. Kaufmann, D. J. Brody, T. Hickman, E. W. Gunter and D. C. Paschal, "Exposure of the US Population to Lead, 1991-1994," Environmental Health Perspectives, Vol. 106, No. 11, 1998, pp. 745-750. doi:10.1289/ehp.98106745

[2] CDC, “Lead,” 2011. http://www.cdc.gov/nceh/lead

[3] R. Levin, et al., "Lead Exposure in US Children, 2008: Implications for Prevention,” Environmental Health Perspectives, Vol. 116, No. 10, 2008, pp. 1285-1293. doi:10.1289/ehp.11241

[4] R. P. Maas, S. C. Patch, D. M. Morgan and T. J. Pandolfo, "Reducing Lead Exposure from Drinking Water: Recent History and Current State," Public Health Reports, Vol. 120, No. 3, 2005, pp. 316-321.

[5] CDC, "Healthy People 2020 Summary of Objectives for Environmental Health,” 2011. http://healthypeople.gov/2020/topicsobjectives2020/pdfs/ EnvironmentalHealth.pdf

[6] S. Reynolds, R. Seem, L. Fourtes, N. Sprince, J. Johnson,
L. Walkner, W. Clark and P. Whitten, "Prevalence of Elevated Blood Leads and Exposure to Lead in Construction Trades in Iowa and Illinois," American Journal of Industrial Medicine, Vol. 36, No. 2, 1999, pp. 307-316. doi:10.1002/(SICI)1097-0274(199908)36:2<307::AID-AJ IM10>3.3.CO;2-M

[7] D. C. Bellinger, "Lead Neurotoxicity in Children: Decomposing the Variability in Dose-Effect Relationships," American Journal of Industrial Medicine, Vol. 50, No. 10, 2007, pp. 1-9.

[8] J. M. Braun, R. S. Kahn, T. Froehlich, P. Auinger and B. P. Lanphear, "Exposures to Environmental Toxicants and Attention Deficit Hyperactivity Disorder in US Children," Environmental Health Perspectives, Vol. 114, No. 12, 2006, pp. 1904-1909. doi:10.1289/ehp.9478

[9] M. L. Miranda, D. Kim, J. Reiter, M. A. Overstreet-Galeano and P. Maxson, "Environmental Contributors to the Achievement Gap,” NeuroToxicology, Vol. 30, No. 6, 2009, pp. 1019-1024. doi:10.1016/j.neuro.2009.07.012

[10] D. C. Bellinger, "Lead Neurotoxicity and Socioeconomic Status: Conceptual and Analytical Issues,” Neuro-Toxicology, Vol. 29, No. 5, 2008, pp. 828-832. doi:10.1016/j.neuro.2008.04.005

[11] S. G. Gilbert and B. Weiss, "A Rationale for Lowering the Blood Lead Action Level from 10 to $2 \mu \mathrm{g} / \mathrm{dL}$," NeuroToxicology, Vol. 27, No. 2006, 2006, pp. 693-701.

[12] N. C. G. Freeman, “Children’s Risk Assessment,” In: M. Robson and W. Toscano, Eds., Risk Assessment for Environmental Health, John Wiley \& Sons, Inc., San Francisco, 2007, pp. 315-344. doi:10.1002/pd.1685

[13] M. A. Pokras and M. R. Kneeland, "Lead Poisoning: Using Transdisciplinanry Approaches to Solve an Ancient Problem,” EcoHealth, Vol. 5, No. 3, 2008, pp. 379-385. doi:10.1007/s10393-008-0177-X

[14] J. O. Nriagu, "Occupational Exposure to Lead in Ancient Times," Science of the Total Environment, Vol. 31, No. 2, 1983, pp. 105-116. doi:10.1016/0048-9697(83)90063-3

[15] FDA, “Lead Based Paint Poisoning Prevention,” Title 42Chapter 63, 1971.

[16] CPSC, “CPSC Announces Final Ban on Lead-Containing Paint (Release \#77-096),” 1977.

[17] “Consumer Product Safety Improvement Act of 2008,” 110th Congress, Public Law 110-314, 2008.

[18] "Residential Lead-Based Paint Hazard Reduction Act of 1992,” 102nd Congress, Title X, 1992.

[19] EPA, "Lead; Identification of Dangerous Levels of Lead," 40 CFR Part 745, 2001.

[20] EPA, "Lead Emissions from Piston-Engine Aircraft Using Leaded Aviation Gasoline," EPA-HQ-OAR-20070294, 2010.

[21] EPA, “Lead Air Quality Standards,” 40 CFR Part 50. 1971, 1-14-2010.

[22] EPA, "Reducing Toxic Emissions from Power Plants," 2011. http://www.epa.gov/airquality/powerplanttoxics

[23] EPA, “Lead and Copper Rule,” 40 CFR Part 141, 1991.

[24] EPA, "Commonly Asked Questions: Section 1417 of the Safe Drinking Water Act and the NSF Standard,” 2011. 
http://water.epa.gov/lawsregs/rulesregs/sdwa/lcr/lead_nsf standard.cfm

[25] EPA, “Corrosion, Scaling, and Metal Mobility Research,” 2011. http://www.epa.gov/nrmrl/wswrd/cr/corr_res_brass.html

[26] CDC, “Blood Lead Levels in Children,” 2012. http://www.cdc.gov/nceh/lead/ACCLPP/Lead_Levels_in_ Children_Fact_Sheet.pdf

[27] B. S. Schwartz and H. Hu, "Adult Lead Exposure: Time for Change," Environmental Health Perspectives, Vol. 115, No. 3, 2007, pp. 451-454. doi:10.1289/ehp.9782

[28] Association of Occupational and Environmental Clinics, "Medical Management Guidelines for Lead-Exposed Adults," 2011.

http://www.aoec.org/documents/positions/MMG_FINAL. pdf

[29] M. Ottlinger, R. Zumwalde, R. Roscoe, M. Kosnett, K. Hipkins, R. Meister and B. Materna, "Adult Blood Lead Testing: A Pivotal Role for Labs in Interpretation and Surveillance," Clinical Laboratory News, Circle No. 165, 2002, pp. 13-15.

[30] CDC, "Children with Elevated Blood Lead Levels Related to Home Renovations, Repair, and Painting Activities-New York State, 2006-2007,” MMWR Morbidity and Mortality, Vol. 58, No. 3, 2009, pp. 55-58.

[31] J. M. Gaitens, S. L. Dixon, D. E. Jacobs, J. Nagaraja, W. Strauss, J. Wilson and P. J. Ashley, "Exposure of US Children to Residential Dust Lead, 1999-2004: I. Housing and Demographic Factors," Environmental Health Perspective, Vol. 117, No. 3, 2009, pp. 461-467.

[32] EPA, "Renovation, Repair and Painting (RRP)," 40 CFR Part 745, Subpart E, 2010.

[33] A. Alert, "EPA Issues Proposed Changes to RRP as a Result of Settlement," Alliance Alert Monthly Electronic Newsletter, Vol. 9, No. 9, 2009, pp. 1-7.

[34] EPA, “Training Courses,” 2011. http://www.epa.gov/lead/pubs/training.htm

[35] EPA, "Lead; Requirements for Hazard Education before Renovation of Target Housing; Final Rule,” 40 CFR Part 745, 1998.

[36] EPA, “TSCA Section 402/404 Lead-Based Paint Renovation Program: 40 CFR Part 745 Subpart E: Residential Property Renovation State, Territorial and Tribal Program Authorization Application Guidance,” 2011. http://www.epa.gov/lead/pubs/statetribalguidance.pdf

[37] EPA, “Lead Abatement Professional,” 2011. http://www.epa.gov/lead/pubs/traincert.htm

[38] EPA, "Lead In the News," 2011. http://www.epa.gov/lead/new.htm

[39] Department of Housing and Urban Development, “HUD Lead Safe Housing Rule, 24 CFR 35, subparts B through R,” Department of Housing and Urban Development, 2004.

[40] DOE, "Weatherization Assistance for Low Income Persons,” 2011. http://www.eere.energy.gov/wip/wap.html

[41] DOE, "Interim Lead-Safe Weatherization (LSW) Guidance: Weatherization Program Notice 08-6," WPN 08-6,
2008.

[42] DOE, "Weatherization Health and Safety Notice: Weatherization Program Notice 11-6,” WPN 11-6, 2011.

[43] Montana Weatherization Center, "Lead-Safe Weatherization (LSW) Benchmark Curriculum Revised 2008,” 2011. http://www.weatherization.org/lswx.html

[44] “American Recovery and Reinvestment Act of 2009,” 111th Congress, Title V111, 2009.

[45] DOL, “Lead,” 2011. http://www.osha.gov/SLTC/lead/index.html

[46] NIOSH, "Preventing Lead Poisoning in Construction Workers,” DHHS (NIOSH) Publication No. 91-116a, 1997.

[47] NIOSH, "NIOSH's Pocket Guide to Chemical Hazards," DHHS (NIOSH) Publication No. 2005-149, 2005.

[48] A. Sussell, C. Hart, D. Wild and K. Ashley, “An Evaluation of Worker Lead Exposures and Cleaning Effectiveness during Removal of Deteriorated Lead-Based Paint," Applied Occupational and Environmental Hygiene, Vol. 14, No. 3, 1999, pp. 177-185. doi:10.1080/104732299303142

[49] L. Yiin, S. Lu, S. Sannoh, B. Lim and G. Rhoads, "Evaluation of Cleaning Methods Applied in Home Environments after Renovation and Remodeling Activities,” Environmental Research, Vol. 96, No. 2, 2004, pp. 156-162. doi:10.1016/j.envres.2004.01.007

[50] EPA, “Criteria for Classification of Solid Waste Disposal Facilities and Practices and Criteria for Municipal Solid Waste Landfills: Disposal of Residential Lead-Based Paint Waste; Final Rule,” 40 CFR Parts 257 and 258, 2003.

[51] "Resource Conservation and Recovery Act (RCRA)," 96th Congress, 40 CFR Parts 260-299, 1976.

[52] "Hazardous and Solid Wastes Amendments of 1984," 98th Congress, P.L. 98-616, 98 Stat. 3224, 1984.

[53] A. Yassin, J. Martonik and J. Davidson, "Blood Lead Levels in US Workers,” Journal of Occupational and Environmental Medicine, Vol. 46, No. 7, 2004, pp. 720-728. doi:10.1097/01.jom.0000131789.37592.d1

[54] F. Rabito, S. Perry, O. Salinas, J. Hembling, N. Schmidt, J. Parsons and P. Kissinger, “A Longitudinal Assessment of Occupation, Respiratory Symptoms, and Blood Lead Levels Among Latino Day Laborers in a Non-Agricultural Setting,” American Journal of Industrial Medicine, Vol. 54, No. 5, 2011, pp. 366-374. doi:10.1002/ajim.20919

[55] B. Materna, D. Harrington, P. Scholz, S. Payne, H. Stubbs, K. Hipkins, E. Merideth, L. Kirsch, G. Lomax, P. Coyle and C. Utratsu, "Results of an Intervention to Improve Lead Safety among Painting Contractors and Their Employees," American Journal of Industrial Medicine, Vol. 41, No. 2, 2002, pp. 119-130. doi:10.1002/ajim.10034

[56] Weatherization Assistance Program Technical Assistance Program, "FAQs-Lead Safe Weatherization,” 2011. http://www.waptac.org/Additional-Pages/FAQ-Lead-SafeWeatherization.aspx

[57] G. Reames, S. Brumis and M. Nicas, “Task-Specific Lead Exposure during Residential Lead Hazard Reduction Projects," Applied Occupational and Environmental Hygiene, Vol. 16, No. 6, 2001, pp. 671-678. 
doi:10.1080/10473220118123

[58] M. Goldberg, N. Clark, S. Levin, N. Zuckerman and J. Doucette, "An Assessment of Lead Controls for Torch Cutting and Rivet Removal on Steel Structures,” Applied Occupational and Environmental Hygiene, Vol. 15, No. 5, 2000, pp. 445-452. doi:10.1080/104732200301403

[59] P. cholz, B. Materna, D. Harrington and C. Utratsu, "Res- idential and Commercial Painters' Exposure to Lead during the Surface Preparation,” AIHA Journal, Vol. 63, No. 1, 2002, pp. 22-28. doi:10.1080/15428110208984687

[60] H. Mason, F. Gallagher and D. Sen, "Window Renovation and Exposure to Lead-an Observational Study," Occupational Medicine, Vol. 55, No. 8, 2005, pp. 631634. doi:10.1093/occmed/kqi159 